Jurnal The Messenger, Vol. 10, No. 1, January 2018, pp. 113-123

P-ISSN: 2086-1559, E-ISSN: 2527-2810

DOI: $10.26623 /$ themessenger.v10i1.711

\title{
Entman Framing Analysis of Food Governance in Online Media
}

\section{Analisis Framing Entman Berita Tata Kelola Pangan di Media Online}

\author{
Diana Anggraeni ${ }^{1,2}$ \\ ${ }^{1}$ The Doctoral Student, Institut Pertanian Bogor, Jl. Raya Dramaga Kampus IPB \\ Dramaga Bogor 16680, Indonesia \\ ${ }^{2}$ Lecturer at the Faculty of Communication Sciences, Universitas Pancasila, Jl. Raya \\ Lenteng Agung Timur No. 56-80, Srengseng Sawah, Jakarta Selatan 12640, Indonesia \\ *e-mail: dachsp@cbn.net.id
}

\begin{abstract}
The article aim is to understand how kompas.com dan sindonews.com on the period of 16 October 2017 up to 21 October 2017 framing the news related to food governance in Indonesia using Entman Framing Analysis. Entman Framing is an alternative method to see media differentiation in reveal the reality. According to the researcher, the two media possess its own differentiation in interpreting those realities, so that media could be considered as reader mindset influencer. The concept and theory of the article is agenda setting, reality construct, Entman Framing, news and online media. The article method is qualitative using news article as analysis unit. The result show that the two online media emphasize issue about food governance management system. But the assertion of the two news are different; kompas.com tend to build and develop the village and farmer regeneration aspect, while sindonews.com emphasized on reinforcement the management system of food governance.
\end{abstract}

Keywords: News, Management System, Entman Framing, Online Media.

\begin{abstract}
Abstrak
Artikel ini bertujuan untuk memahami bagaimana kompas.com dan sindonews.com periode 16 Oktober 2017 hingga 21 Oktober 2017 membingkai pemberitaan terkait tata kelola pangan di Indonesia, melalui analisis Framing Model Entman. Framing Entman merupakan sebuah alternatif metode untuk melihat perbedaan media dalam mengungkapkan sebuah realitas. Kedua media yang digunakan ini menurut penulis mempunyai perbedaan dalam mengintepretasikan realitas tersebut, sehingga media dianggap bisa membentuk pola pikir dari pembacanya. Teori dan konsep dalam penulisan ini adalah agenda setting, konstruksi realitas, Framing Entman, berita dan media online. Artikel ini menggunakan metode kualitatif dengan teks berita sebagai unit analisisnya. Hasil penulisan ini menunjukkan bahwa kedua media online menekankan isu mengenai tata kelola kedaulatan pangan. Namun penonjolan keduanya berbeda di mana kompas.com lebih kepada aspek membina dan mengembangkan desa serta regenerasi petani, sementara sindonews.com kepada penguatan sistem kelola pangan.
\end{abstract}

Kata Kunci: Berita, Tata Kelola, Framing Entman, Media Online.

Copyright $@ 2018$ Universitas Semarang. All rights reserved.

\section{Introduction}

Mass media nowadays run into a rapid growth development. The mass media have ability in providing information about phenomenon or social reality towards people. Right now the mass media undergo a metamorphosis into new media (online) that have great impact to influence the reader through the news they delivered (McQuail, 2010: 136). Mass media has three characteristics: first, as a business seeking profit to support their activities. Second, if associated with technology, mass media will also change both

Article History: Received November 24, 2017; Revised January 21, 2018; Accepted January 28, 2018; Published January 31, 2018 
pattern of distribution and consumption, and the third, mass media is a reflection of society in which the media located. Internet media become a new mass media that performs integrated delivery on print, audio and video (Biagi, 2010: 13). Putri research result (2012) shows that the media has their own ideology in interpreting and understanding an event. With ideological differences, news on mass media can be presented differently.

The message conveyed by the mass media generally comes from a social reality that occurs. News is made by a mass media to be consumed in accordance with its need. People needs information. Therefore, the mass media are required to provide and deliver the latest information, and based on the realevents that occurred. So that audience get the real news as it is. In her research, Astutik (2015) stated that news and opinions will guide the public to connect the various realities that were separated previously by geographic and psychographic factors into a sequence that is easy to understand and follow. News is information. According to the constructivism, news is a construction based on the frame, opinion or viewpoints of what the media see on the field (Eriyanto, 2012: 7). It can be said that the reality can be formed to influence the readers. Construction of reality is an attempt to retell the event or phenomenon that occurred. The content of an outline is an opinion that has been constructed. Framing is done by media administrator, in which this part are actively involved in the news production process. On the initial making, the news is made by journalists based on what is seen and felt in the field so that it is objective. But if it becomes an opinion or judgment then it becomes subjective. It happens because individual judgments in understanding a reality have a great variation (Bungin, 2008: 13). This also happens to news in the online media.

The source of the article comes from two national online mass media, there are kompas.com and sindonews.com in broadcasting the food governance committed by the government. Both of the online media broadcast and construct the news into an interesting news and can attract readers on the period of 16 October 2017 to 21 October 2017. The sovereignty, governance, and food institution strengthening became an issue that was raised and became the theme of a discussion at several universities in Indonesia. This issue was taken to inquire the fulfillment of human rights to brag about right of food fulfillment that guaranteed in the Republic of Indonesia Constitution 1945 (UUD 1945) as a basic component to embody the qualified human resources (www.gatra.com). The event was attended by Members of the Presidential Advisory Council (Wantimpres) Sidarto Danusubroto which is the Chairman of the Board of Directors of the National Conference 2017 (Dewan Pengarah Rembuk Nasional 2017). Chairman of the National Council Firdaus Ali said food security is one of the three things that ensure the nation betterment. The event became a forum to criticize and provide input to the government that has been running for 3 years.

Food security is a condition related to the management of food as a whole. Prabowo Research (2010) said that food security includes the first, the availability factor in terms of food supply guarantee in fulfill the needs such as quality, quantity, diversity and security for the whole society. The second factor is an effective and efficient distribution system, so it can guarantee and be able to distribute the food sustainably and maintain the price stability. The third factor is to meet people's consumption patterns that refer to quality, nutrition, security.

Indonesia according to Armawi research in 2009, said Indonesia is still depends totally on imported food. Indonesia became the second largest importer in the world, 
whereas Indonesia well known as an agrarian country. Purwaningsih (2008) research stated that food security aspect covers 4 aspects, there are food availability, food security, food equality distribution and food affordability. If referring to the food security concept according to Law number 7 of 1996 (UU No. 7/1996) is the condition of food fulfillment for households which is reflected from the availability of adequate food, both quantity and quality, safe, equitable, and affordable then the food security problem is well managed by the government. Those law then became one of the topics that are often used by political commodities to criticize the government at any time if there is a problem related to those food corporate government.

In relation to the above news, framing analysis used an alternative model of analysis that can reveal the news in the online media in framing the reality. Despite both online media the author believe having the same attitude in supporting the government but have ideological differences in presenting the news, especially related to development in Indonesia. Framing according to Entman (1993) basically involves the selection of some of the realities that are highlighted through the text. The use ofEntman framing is to see how the online media address, construct and framing reality, how that reality show and how put its meaning. Then look for who is controlling and controlled, as well as who get the benefit or disadvantaged over the news. As we know that the Entman model emphasizes on the selection of issues and aspects projections. The aspectthen will be selected to be display, because not all material from the news will be raised on the news.

Based on the description above, the problem to be studied in the article is how the two online media: kompas.com and sindonews.com framing the news about the food corporate governance in the period of 16 October 2017 to 21 October 2017. The social construction of reality is an individual social process that happen continuously through action and interaction. The reality is owned, experienced and created together subjectively (Bungin, 2008: 13). Peter L. Berger and Thomas Luckmann in 1966 depict that Humanity is a product of society which is dialectic, dynamic and plural, and those happens continuously. Berger and Luckman states that man and society is a product that has an influence, dynamic and plural (Eriyanto, 2012: 17) and the effect divides into three, those are externalization which means meaningful efforts of humans expression to the outside world, objectivities which means the result of externalization to see reality and the third is the internalization which means the absorption of the objective world into subjective consciousness, thus are affecting the individual's consciousness in his or her social life.The construction process of reality is an attempt to retell an event, event and circumstance (Hamad, 2004: 11). Media as a news channel and take its role to inform the audience. Therefore, the process of forming and making news can not be separated from the media efforts in reconstructing the news. Sobur (2012: 88), stated the media content is the result of reality construction using language as its tool. Journalists and media will took their effort to create the reality according to their subjective perspective and judgment.

Agenda setting is a theory that seeks to see what the current media agenda is going to be displayed to the public through the prominence of certain issues (Tamburaka, 2012: ix). Littlejohn and Foss (2009: 416) divide the agenda setting process into 3 (three), those are:

1. Media agendas to be formatted for visibility dimensions (number and level of news bulging), audience salience (valence level), valence (fun or unpleasant way of preaching an event). 
2. Agenda Audience, related to how much media power can influence or interact with the public. His dimensions are familiarity, personal salience and favorability.

3. Policy Agenda to see the interaction of the effects of the public agenda on the policy agenda that are important. This dimension is related to support, likelihood of action, the freedom of action.

The mass media is also considered as the center of truth-determination with the ability to transfer the two elements of awareness and information into the public agenda by directing awareness and public attention into issues that is seems important by the mass media.

Entman Framing Analysis is an analytical model that see the purpose behind a news story in the media. Framing analysis taken from an issue or reality framed by the media, then understood and interpreted so it will havecertain meaning (Eriyanto, 2012: 3-10). Entman in his journal entitled "Framing: Toward Clarification of a Fractured Paradigm" in 1993 states that framing is now a very popular tool and is used extensively in communication research, so framing analysis is related to how a news idea is conveyed in media through the text and see how the impact of the news is generated through the content of the message and how it will affect audience way of thinking. The two main essences of the framing analysis (Eriyanto, 2012: 222) are, firstly the selection of issues, as the process of selecting facts from diverse realities. To see how an event is interpreted and related to the part which is will be covered or not. Second, the emphasis in which how a fact is written. The use of words, sentences and drawings of what will be used to support the writing. How the issue is selected, written and displayed to the audiences. This Entman concept refers to the operationalization of four dimensions:

\begin{tabular}{|c|l|}
\hline Defining The Problem & $\begin{array}{l}\text { First element as master framing. Here, we can see how an } \\
\text { event is understood. Whether the news is positive or } \\
\text { negative. }\end{array}$ \\
\hline Diagnose Causes & $\begin{array}{l}\text { Find and estimate the source of the problem. This } \\
\text { dimension seeks or seeks to know how the event is } \\
\text { understood, occurs and what or who is considered to be the } \\
\text { source of the cause. }\end{array}$ \\
\hline Make Moral Judgement & $\begin{array}{l}\text { An assessment of the moral values used to legitimize or } \\
\text { argue for an action or idea being made. }\end{array}$ \\
\hline $\begin{array}{c}\text { Treatment } \\
\text { Recommendation }\end{array}$ & $\begin{array}{l}\text { What efforts or solutions are offered and done to resolve the } \\
\text { problem. This settlement depends on the issue and who } \\
\text { caused the problem (the first element) }\end{array}$ \\
\hline
\end{tabular}

Table 1. The Entman Framing Analysis Method

(source: Entman cited by Eriyanto, 2012: 222-224)

Entman framing analysis is also used to see the suppression of delivery criteria and presentation of what editor or journalist uses in constructing the events, framing the news and then present it, so that the news presented becomes more noticeable, meaningful and impressed the reader.

News Text is anything written and explained in long script in the form of a letter or newspaper. Text is also interpreted as a set of marks transmitted from the sender to the recipient through certain media uses certain codes (Budiman quoted by Sobur, 2012: 53). The text in the media is then analyzed to determine the tendency aspects of messages that delivered by the media whether it appear or not. News is something valuable in an event. Soehoet (2003: 23) says the news is a description of the events or 
content which human needs for himself and his readers to embody his life philosophy. There are five categories of news known in journalism (Tuchman quoted by Eriyanto, 2012: 126-130) they are Hard News, Soft News, Spot News, Developing News and Continuing News. News related to the food corporate governance on the news media can be concluded as developing news. All of the news must contain facts that are included in news items $5 \mathrm{~W}+1 \mathrm{H}$ (Chaer, 2010: 17-18), what (events that contain the facts of what happened), who (who or people who were and are involved in the reports), why (why it happened or background that makes the event), where (identification of the occurrence event location), when (the time it happens), and how (how the process of an event). Media is a way or process of delivering a message to audiences. Online media is a telecommunication-based media or multimedia (computer and internet) that presented online at the website.

Online media is known by the term cyber media or new media and is an online journalistic product that news are produced and distributed through internet media. Online journalism is associated with the process of reporting, writing and disseminating the news online which use connectivity or connection, internet which means interconnected computer network as well as website which means a page containing information in the form of text, video, audio and picture. There are several types of online media and ownership that is included in the category of news websites (news online media) and websites according to Romli (2012: 30-34), those are: news sites from newspaper; news sites from radio broadcasting media; news sites from television broadcasting media; sites news that are unrelated to all of those three media; and news index sites that contain links from other online news sites. An online mediaresearched by the writer included in the news site in online media. Online mediapredominance if it compared among other conventional media: the speed on the news update (updating), can be accessed anywhere right after it's uploaded, the flexibility in loading and editing. The news in the online media keeping neatly. All documents that ever loaded are stored in the data bank, you can use the existing index on the media if you want to search it again in the future (Romli, 2012: 33). The shortcoming of online media is very dependent on the computer device and internet connection. Online media content in Indonesia must obey and complyto the Journalistic Code of Ethics and the Guide to Cyber Protection (Pedoman Pemberitaan Media Siber (PPMS)), authorized by the Press Council (Dewan Pers) on 3 February 2012.

Food Security according to Law No. 7 of 1996 Article 1 (UU No. 7/1996, Pasal 1), food is anything that originated from biological and water, whether treated or untreated, which is used as a food or beverage for human consumption, including food additives, food raw materials, and other materials used in the process of preparing, processing, and or preparing food or drink. Meanwhile Food security in article 17 is fulfillment condition of food in households which is reflected on the availability of adequate food, both quantity and quality, safe, equitable, and affordable. The definition of food security is then reinforced by Government Regulation No. 68 of 2002 (Peraturan Pemerintah No. 68/2002), which food security is defined as the condition of the fulfillment of food for the household which is reflected from the availability of adequate food, both quantity and quality, safe, equitable and affordable. Food management in Indonesia should be done well, reminds that the consumption needs to cope 257.9 million people (tribunenews.com). Those reasons as the basic of roles and obligations of country become dominant to provide adequate food that will supply food 
production in line with the increasing number of people each year (Purwaningsih, 2008).

\section{Methodology}

The approach used on the article is a qualitative. The qualitative method does not use numbers to answer the writer's questions and try to understand the phenomenon that the subject experience holistically and intact, and describe in the form of words and languages which is explained specifically natural (Moleong 2007: 6-7). Qualitative approaches uses text, images, to explain the behavior and specific attitudes of research object (Creswell, 2015: 258).

The author use the qualitative approach because the data that collected and generated later in the form of written, later would be viewed as a whole and thorough through kompas.com and sindonews.com when making news about the food corporate governance. Using the analysis then the writer would see in depth how the online media produce news text on the media.

The method that use to analyze data using descriptive methodin which the writer aim is to describe systematically facts or characteristics of a particular population or a particular field. Descriptive writing study the problems and data in society, including the relation, activities, attitudes, views and influences of a phenomenon (Kriyantono, 2010: 69). The descriptive methoddoes not seek or explain the relation, and does not test the hypothesis.

The method that writer use is the analysis of Entman Framing to see and analyze how these two online media presents news about the food corporate governance and then make it into a news. Defining the problem use as a frame to see an event on the first sight. Then look for the cause of the problem by determining what and who the actor behind the news. Furthermore, moral decisions will be made to explain the values on the news, then come into the final stage of what should be taken and put forward to solve problem thoroughly.

The writing is done based on the news on kompas.com and sindonews.com. While the materials uses by the writer are the news about governance of food sovereignty 16 21 October 2017. The news is as follows:

\begin{tabular}{|c|c|c|c|}
\hline No. & Journalist & Title & $\begin{array}{c}\text { Date and } \\
\text { Uploaded Time }\end{array}$ \\
\hline 1. & Ramdhan Triyadi & $\begin{array}{c}\text { Tahun Pemerintahan Jokowi-JK, } \\
\text { Kedaulatan Pangan Belum } \\
\text { Baksimal (Jokowi-JK } \\
\text { Government Year, Food } \\
\text { Sovereignty Not Maximized) }\end{array}$ & $\begin{array}{c}\text { 20 October 2017, } \\
\text { 18:54 Indonesia } \\
\text { Western Time }\end{array}$ \\
\hline \multirow{2}{*}{ Resa Eka Ayu } & $\begin{array}{c}\text { Krisis Pangan Dunia, Benarkah } \\
\text { dipicu Migrasi Penduduk Desa? } \\
\text { (World Food Crisis, is it Really } \\
\text { Triggered by Migration of the } \\
\text { Villagers?) }\end{array}$ & $\begin{array}{c}\text { 16 October 2017, } \\
18: 11 \text { Indonesia } \\
\text { Western Time }\end{array}$ \\
\hline
\end{tabular}

Table 2. News on Food Sovereignty Governance at kompas.com

\begin{tabular}{|c|c|c|c|}
\hline No. & Journalist & Title & $\begin{array}{c}\text { Date and Uploaded } \\
\text { Time }\end{array}$ \\
\hline 1 & Wahab & Kedaulatan Pangan Jadi Fokus & 21 October 2017, \\
\hline
\end{tabular}




\begin{tabular}{|c|c|c|c|}
\hline Firmansyah & $\begin{array}{c}\text { Pembahasan Rembuk Daerah di IPB } \\
\text { (Food Sovereignty as The Focus of } \\
\text { Discussion on Regional Councils in } \\
\text { IPB) }\end{array}$ & $\begin{array}{c}22: 09 \text { Indonesia } \\
\text { Western Time }\end{array}$ \\
\hline 2 & $\begin{array}{c}\text { Mohammad Atik } \\
\text { Fajardin }\end{array}$ & $\begin{array}{c}\text { Pemerintah Jokowi dinilai Serius } \\
\text { Wujudkan Kedaulatan Pangan } \\
\text { (Jokowi Government considered } \\
\text { Seriously realize Food Sovereignty) }\end{array}$ & $\begin{array}{c}17 \text { October 2017, } \\
\text { Western Time }\end{array}$ \\
\hline
\end{tabular}

Table 3. News on Governance of Food Sovereignty at sindonews.com

The selection of both online media is due to the ideology of both especially in the position as a media that often preach the development in Indonesia during the President Joko Widodo reign. Kompas.com is known as a media that supports the current government and sindonews.com is a private media.

Generally the research on framing convey about the differences on the message on the media due to ideological differences. But in this article, the novelty that taken by the two media have the same vision to support the current government. However, the results of the analysis show interest tendencies that are contained in the theme selection and assertion of the issues on the news presented.

\section{Result and Discussion}

Online media as well as other mass media has the characteristics as news disseminator in the form of a news event or reality that occurred to the audience. Kompas.com and sindonews.com are two online media that raised the news about the problem of food security in commemorating World Food Day on 16 October 2017.

Both media online even as the government supporting media framing and construct the reality of food security from different angle. It can be seen on the evident of all elements define on the problem of the four news samples used, in which kompas.com highlighted the problem of food security and food governance and the lack of regeneration of young farmers as the main problem in the reality of managing food management. Sindonews.com is also in line with kompas.com which is raised the issue of food security in addition to the seriousness of the current government to realize a strong food sovereignty.

Both of the media have the same concern, but sindonews.com on the news on October 17, 2017, raised the issue not only about food security, but also added the element of food security as proof of the government seriousness which is talked not only to the fulfillment of food but to improve the health of the Indonesian people and according to Firdaus Ali as the chairman of the National conference which is states in paragraph 9, "For the first time in the history of Indonesian government the government pay attention to the food and security problems". In paragraph 10 of the diagnose cause element, Sindonews also stated that "The previous government only focused on food hardiness not on food security." The emphasis that highlighted here is to inform the audience that during the President Joko Widodo reign the issue became a priority.

Media try to change the audiences attitudes and behavior through the information being delivered. Information on the news certainly has an influence in making the opinion. It become the sole purpose why a media construct a reality. As Tamburaka (2012) points out, that issues on the agenda setting will be displayed through the emphasis a news. Here both media emphasize that there is a problem in food 
governance in Indonesia, so the current food governance becomes an issue that is worrying because of the existence of the mafia and itcan not be eliminated. In addition the lack of young generation of farmers which is not interested in becoming farmers because they think that the job was not be able to increase his economy level and can not support the prestige, so the youngsters tend to choose being a labor or become the employee of other sectors.

The other problem is about agricultural land which is invested to private parties. Tejo Wahyu Jatmiko as the National Coordinator of the Alliance of Prosperous Villages (Aliansi Desa Sejahtera (ADS)), stated that "in which related to the land, agricultural infestation need to be done carefully, due to thepolicy from the previous government still has not been revoked, which is the policy opens opportunities for private investors to open agricultural land without the obligation to sell its agricultural products to Indonesia" (kompas.com, October 16, 2017 paragraph 8 on the element of diagnose causes). Which is become the focus of kompas.com informed about the food mafia. Indonesia is a fertile country and suitable for agricultural sector. But it is used by 'individual' to dredge all existing agricultural produce for personal benefit. A media opinion to influence readers that the lack of food governance is the result of poor management of previous government. Blaming the previous reign seem unfair, but here kompas.com on 16 October 2017 want to share that the lack of management is the impact of the previous government policy so it is not appropriate blaming the present reign without seeing the root of the problem before.

The results of the analysis using the reality theory construction, shows a construction made by both online media. Berger and Luckman (Eriyanto 2012) the reality construction has three processes, there are externalization which means the human expression to the outside world, on the news of both online media, journalists make news based on information that received and then writenews according to his opinion. On the second stage of objectivities, to improve food security there is some construction offered, thus are the Make Moral Judgment dimension that invites readers to nurture and build up villages and to encourage the youngsters interestto be attracted to the agricultural sector (kompas.com 16 October 2017 paragraph 11 and 12) state that "to attract young people, the government also needs to provide incentives and convenience." At the internalization stage both agree that the problem of food security is our responsibility, as written in kompas.com dated 20 October 2017 paragraph 7 and sindonews.com paragraph 2 dated 21 October 2017, on the Make Moral Judgment dimension states that "to build food security is responsibility of all parties."

The last element on Entman Framing is treatment recommendation. The process of internalization is defined when the media have purpose or has influenced its audience, occurs on the element. On kompas.com dated 20 October 2017 paragraph 11, stated that the problem of not maximized food governance due to the mafia. Kompas.com quotes the explanation of Sidarto Danusubroto (Watimpres), "... if there is a 'player' (mafia) on food, please stop them." In line with sindonews.com dated 21 October 2017 paragraph 5. Here both media explains that there are important things in managing food security and those are the reality. That is why both online media invites the community join to stop the practice. Another alternative settlement raised in the news is the stand to take sides on the agricultural sector, in which the state must be present and act as an investor. Both kompas.com dated 16 October 2017 and sindonews.com dated 21 October 2017 reported the support to the current government policy. In addition Sindonews also raised the commitment of the government who 
seriously want to solve the problem of food security governance by reporting that there is budget increase in order to strengthen food governance system on the news dated 16 October2017, those are "... food sovereignty budget rise into to 53, $2 \%$...."

News on the media is a text that can be analyzed to know or see the tendency aspects of messages that delivered by the media whether it appears or not. Related to news on food security governance, the writer see the media's tendency to support the current government with information that affects readers to behave in the same way. Soehoet (2003) says the news is an explanation of some events or consist of human revelation. Those two online media cited the statement source from the government and academics as their news material. This is reasonable thing to do because the National Conference activities in 2017 (Rembuk Nasional 2017) conducted in 16 universities on 14 provinces which the results will be presented nationally. Both news media broadly outlinethe support to the government to solve the food sovereignty problem, even using different construction angle.

The management of food security by the government according to the writer if it refers to the notion that states on the Law number 7 of 1996 (UU No. 7/1996), confirmed that the government has a responsibility. Food security problems associated with the supply, distribution and consumption of food that will be consumed by Indonesian people. Management becomes very important, to reduce food imports from other countries, so that Indonesia as an agricultural country or can be said a state that its economysupported by the agricultural sector can be recovered, it also remain to provide guidance to the young generation so that the farmers crisis can be avoided as well and redevelop the agricultural village as an agricultural center with the ability to ensure all provided from the agricultural sector, such as training, the new materials value, fertilizers including the reselling value.

The Indonesian government should also begin to be serious in undertake the food corporate governance with regard to the domestic production pattern in all lines of food production. Not only agriculture but also fisheries, plantation agriculture and farms in order to maintainthe stabilitythe needs of food in Indonesia. As a basic needs of human life, the policy of food management also involves society elements to encourage and revive the development on these sectors through programs which provide a good profit, so that the young generation would re-develop and promote the food sectors, such as reducing imports by increasing domestic production, providing agricultural education, providing incentives for manufactured products, the supplies of asset to help food management andits distribution channels, and the last began to rethink in achieving rice self-sufficiency.

\section{Conclusion}

From the analysis of the both online media, the writer concludes the news about the food soveregnty corporate governance as follows:

The news on kompas.com emphasizes on food security issues support the government to foster and develop village as an agriculture center and to encourage the interest of young generation so that they attracted to the agricultural sector. This is the concern of kompas.com due to one of the causes of the food crisis caused by high levels of rural migration.

Sindonews.com also showed support for the food governance by raising the issue from different perspective. The emphasis of Sindonews is strengthen the food governance system and the government seriousness to solve the problem. 
Both media online has a different ideology in understanding and framing the reality then to be constructed into the news. Thus were done to influence the public to have similar point of view withthe news that presented by the media. As the media that support the government, it can be seen that both kompas.com and sindonews.com trying to persuade and influence readers to actively participate in support the government.

\section{Acknowledgement}

The article was created as part of the task of Communication Strategy and Developmental Politics, The Faculty of Human Ecology, Institut Pertanian Bogor. So that the writer would like to thanked the Lecturer (Sarwititi S. Agung) as a lecturer of the course. Great thanks for the support, also to all the friends the Doctoral Degree Program Agricultural and Rural Development Communication 2017 (Komunikasi Pembangunan Pertanian dan Pedesaan (KMP-IPB)).

\section{References}

Armawi, A. (2009). Memaknai Kembali Ketahanan Pangan. Jurnal Ketahanan Nasional, 14 (1).

Astutik, P.W. (2015). Framing Pemberitaan Citra Politik Capres 2014 di Harian Solopos. Jurnal The Messenger, 7 (2), 9-17.

Biagi, S. (2010). Media Impact, Pengantar Media Massa. Jakarta: Salemba Humanika.

Bungin, B. (2008). Konstruksi Sosial Media Massa. Jakarta: Kencana Prenanda Media Group.

Chaer, A. (2010). Bahasa Jurnalistik. Jakarta: Rineka Cipta.

Creswell, J.W. (2015). Research Design: Pendekatan Kualitatif, Kuantitatif dan Mixed. Yogyakarta: Pustaka Pelajar.

Entman, R.N. (1993). Framing: Toward Clarification of a Fractured Paradigm. Journal of Communication. Autumn 1993, 51-58.

Eriyanto. (2012). Analisis Framing: Konstruksi, Ideologi dan Politik Media. Yogyakarta: LKiS.

Hamad, I. (2004). Konstruksi Realitas Politik dalam Media Massa. Jakarta: Yayasan Obor Indonesia.

Kriyantono, R. (2010). Teknik Praktik Riset Komunikasi Disertasi Contoh Praktis Riset Media, Public Relations, Advertising, Komunikasi Organisasi, Komunikasi Pemasaran. Jakarta: Kencana Pranada Media Group.

Littlejohn, S.W., Foss, K.A. (2009). Teori Komunikasi, Edisi 9. Jakarta: Salemba Humanika.

McQuail, D. (2010). Mass Communication Theory, 6th edition. London: SAGE Publications Ltd.

Moleong, J.L. (2007). Metodologi Penulisan Kualitatif. Bandung: PT Remaja Rosdakarya.

Prabowo, R. (2010). Kebijakan Pemerintah dalam Mewujudkan Ketahanan Pangan di Indonesia. Jurnal Ilmu-Ilmu Pertanian, 6 (2), 62-73.

Purwaningsih, Y. (2008). Ketahanan Pangan: Situasi, Permasalahan, Kebijakan, dan Pembedayaan Masyarakat. Jurnal Ekonomi Pembangunan, 9 (1).

Putri, A.N.I. (2012). Analisis Framing Berita Demonstrasi Mahasiswa Semarang Terkait Kenaikan Harga BBM pada TV Borobudur. Jurnal The Messenger, 4 (2), 19-26.

Romli, A.S.M. (2012). Jurnalistik Online. Bandung: Penerbit Nuansa Cendekia.

Sobur, A. (2012). Analisis Teks Media. Bandung: Remaja Rosdakarya. 
Soehoet, A.M.H. (2003). Dasar-Dasar Jurnalistik. Jakarta: Yayasan Kampus Tercinta IISIP.

Tamburaka, A. (2012). Agenda Setting Media Massa. Jakarta: RajaGrafindo Persada. Undang-undang Republik Indonesia No. 7/1996 tentang Pangan.

http://jateng.tribunnews.com/2016/09/01/data-terkini-jumlah-penduduk-indonesia-2579juta-yang-wajib-ktp-1825-juta

https://www.gatra.com/nusantara/nasional/291216-rembuk-nasional-ipb-bahaskedaulatan-pangan-tata-kelola-dan-penguatan-kelembagaan-pangan

https://nasional.sindonews.com/read/1250529/15/kedaulatan-pangan-jadi-fokuspembahasan-rembuk-daerah-di-ipb-1508598589

https://nasional.sindonews.com/read/1249128/15/pemerintah-jokowi-dinilai-seriuswujudkan-kedaulatan-pangan-1508229813/13

http://regional.kompas.com/read/2017/10/20/18544831/3-tahun-pemerintahan-jokowijk-kedaulatan-pangan-belum-maksimal

http://sains.kompas.com/read/2017/10/16/181131123/krisis-pangan-menduniabenarkah-dipicu-migrasi-penduduk-desa 